\title{
Avoiding Malthus 2.0: Why Food Pessimism Leads Nowhere
}

\author{
Christian Fischer* \\ Faculty of Science and Technology, University of Bozen-Bolzano, Italy \\ *Corresponding author: Christian Fischer, Faculty of Science and Technology, University of Bozen-Bolzano, South Tyrol, Italy. \\ To Cite This Article: Christian Fischer. Avoiding Malthus 2.0: Why Food Pessimism Leads Nowhere. Am J Biomed Sci \& Res. 2019 - 6(1). AJBSR. \\ MS.ID.000993. DOI: 10.34297/AJBSR.2019.06.000993.
}

Received: 制 October 29, 2019; Published: 阱 November 05, 2019

\section{Opinion}

Planet Earth's natural resources, such as land, freshwater, raw materials etc., have to be shared among an increasing number of people (and farm animals). Moreover, human life expectancy has continuously increased. Consequently, more people consume for longer, leading to fears whether there is enough for all of them, now and in particular in the future.

One particular concern is about human diets and their resource implications. Globally, agriculture accounts already for up to $40 \%$ of global land use and $70 \%$ of freshwater withdrawals [1]. Moreover, food systems contribute 19-29\% of global anthropogenic greenhouse gas (GHG) emissions of which agricultural production, including indirect emissions resulting from land-cover change, contributes $80-86 \%$ of total food system emissions [2]. In 2013, food represents $97 \%$ of world agricultural production (value) and $23 \%$ of world food production was exported, according to FAOSTAT Production and Trade databases (online). The question is whether humankind can go on consuming food and drink as it currently does.

While food security fears have been with humans for their entire existence, the British scholar Thomas Malthus, at the turn of the 18th century, introduced the notion of the "population trap". Rapid population growth would eventually outstrip agricultural production thus leading to shortages of food supply and starvation. The much more recent concerns about food system sustainability add fears that current agricultural production practices damage environmental ecosystems and world climate, thus threatening the natural resource base of future generations. The current perception is that the very activity of food production that is meant to keep humans alive kills them eventually in the long run.

The definition of diet sustainability is complex since it comprises multiple criteria. However, dietary diversity is a key recommendation for healthy food intake $[3,4]$ while a low consumption of animal products is considered to have minimum negative environmental and climate consequences $[5,6]$.

The UN Food and Agriculture Organization provides data that allow tracking the evolution of both mentioned measures over time. Using FAOSTAT Food Balance Sheets and the indicator food supply (in kcal/capita/day), it is possible to investigate changes in the sustainability of the world's average diet between 1961 and 2013. One measure is the share of daily per capita calorie intake derived from vegetable/plant products (ranging from 0 to 1 ). The other indicator is the variety of vegetable/plant products consumed, measured by the Simpson diversity index [7] (ranging from $0=$ no to 1 = maximum variety).

The numbers show that during the last 50 years the world's average diet became more based on animal products and remained virtually unchanged regarding the variety of vegetable products consumed. The share of $\mathrm{kcal}$ in daily food intake derived from vegetable products decreased from $84.6 \%$ (1961) to $82.2 \%$ (2013), while plant product variety decreased slightly from a Simpson index score of 0.888 to 0.881 . Both changes are comparatively small. At the same time, total world calorie consumption more than tripled (from $2.48 \times 10^{15} \mathrm{kcal}$ per year to $7.59 \times 10^{15} \mathrm{kcal}$ per year).

During the same period, global average life expectancy rates steadily improved. According to [8] and WHO (online), the mean lifespan increased by $48 \%$ from 48 years (1950) to 70.8 years (2013). It is clear that life expectancy is an imperfect human health measure. Nevertheless, it is also a very fundamental one, which cannot be ignored. Moreover, life expectancy depends on multiple factors. Suboptimal diets only account for about $20 \%$ of deaths globally [9].

World per capita agricultural GHG emissions have actually decreased from $890 \mathrm{~kg} \mathrm{CO} 2$ equivalents in 1961 to $719 \mathrm{~kg}$ CO2eq in 
2013, a drop of 19\%, according to the FAOSTAT Emissions database (online). This decrease occurred while simultaneously the share of kcal in daily food intake derived from animal products increased by $2.4 \%$ (as shown above).

Assuming data reliability and method validity, the presented numbers suggest that the nexus between diets and health and climate outcomes is not fully evident at the global level. Therefore, we should avoid Malthus 2.0 - i.e., scientific food pessimism. The world currently produces more food than almost 8 billion people can consume, with a significant share of food calories used as animal feed or as a source for biofuels and still there is food left to be wasted or to be overconsumed, leading to obesity. Not having enough to eat for everyone is a serious problem and a system failure. Not avoiding food surpluses or not using them responsibly and reasonably is just a big shame.

Hence, maybe food system GHG emissions are better tackled at the supply side by tightening production standards in particular for ruminant products, which would cause their costs and prices to rise and their demand and consumption to fall. Moreover, the limitations of dietary contributions to overall health should perhaps be more widely acknowledged. Blaming the good that keeps us alive in the first place for the misery of our actions leads nowhere.

\section{References}

1. (2017) FAO, The future of food and agriculture. Trends and challenges, Rome.

2. Vermeulen S, Campbell B, Ingram J (2012) Climate Change and Food Systems. Annual Review of Environment and Resources 37 (1): 195-222.

3. (2018) WHO. Healthy Diet. Geneva.

4. Willett W, Rockström J, Loken B, Murray C, et al. (2019) Food in the Anthropocene: the EAT-Lancet Commission on healthy diets from sustainable food systems. The Lancet Commissions 393 (10170): $447-$ 492.

5. Searchinger T, Waite R, Hanson C, Ranganathan J, Dumas P, et al. (2018) Creating a Sustainable Food Future: A Menu of Solutions to Feed Nearly 10 Billion People by 2050. World Resources Institute, Washington (DC). p. 96.

6. Smith P, Bustamante M, Ahammad H, Tubiello F, et al. (2014) Agriculture, Forestry and Other Land Use (AFOLU). In: Climate Change 2014: Mitigation of Climate Change. Contribution of Working Group III to the Fifth Assessment Report of the Intergovernmental Panel on Climate Change Edenhofer O. et al. [Eds.] Cambridge University Press, Cambridge, United Kingdom and New York, NY, USA.

7. Simpson E (1949) Measurement of Diversity. Nature 163: 688.

8. Riley J (2005) Estimates of Regional and Global Life Expectancy, 18002001. Population and Development Review 31(3): 537-543.

9. GBD 2017 Diet Collaborators (2019) Health effects of dietary risks in 195 countries, 1990-2017: a systematic analysis for the Global Burden of Disease Study 2017. The Lancet 393 (10184): 1958-1972. 